\title{
sciendo
}

\section{SLOW-RELEASE UREA PARTIALLY REPLACING SOYBEAN IN THE DIET OF HOLSTEIN DAIRY COWS: INTAKE, BLOOD PARAMETERS, NUTRIENTS DIGESTIBILITY, ENERGY UTILIZATION, AND MILK PRODUCTION}

\author{
Hani M. El-Zaiat ${ }^{1,2 *}$, Ahmed E. Kholif ${ }^{3}$, Ibrahim M. Khattab ${ }^{4}$, Sobhy M.A. Sallam \\ 'Department of Animal and Fish Production, Faculty of Agriculture, University of Alexandria, Aflaton St., El-Shatby, P.O. Box 21545, \\ Alexandria, Egypt \\ ${ }^{2}$ Department of Animal and Veterinary Sciences, College of Agricultural and Marine Sciences, Sultan Qaboos University, P.O. Box 34, \\ Postal Code 123, Al-Khod, Oman \\ ${ }^{3}$ Dairy Science Department, National Research Centre, 33 Bohouth St. Dokki, Giza, Egypt \\ ${ }^{4}$ Department of Animal and Fish Production, Faculty of Desert and Environmental Agriculture, Matrouh University, 51744 Matrouh, Egypt \\ •Corresponding author: hani.elzaiat@alexu.edu.eg; hm_elzaiat@yahoo.com
}

\begin{abstract}
The present experiment aimed to evaluate the partial replacement of soybean with slow-release urea (Optigen 1200 ${ }^{\mathrm{TM}}$ ) in the diet of lactating cows for $84 \mathrm{~d}$. Three-hundred multiparous lactating Holstein $(635 \pm 25 \mathrm{~kg}$ of body weight, BW) cows were stratified by live body weight; parity and previous milk production were randomly assigned into two experimental groups with 150 cows per each treatment. In the control treatment, $25 \mathrm{~g}$ soybean meal was replaced by $5.7 \mathrm{~g}$ slow-release urea for $84 \mathrm{~d}$. Optigen treatment did not affect feed intake, daily milk production, milk composition, or milk (feed) efficiency; however, it increased $(\mathrm{P}<0.01)$ total $\mathrm{BW}$ gain and daily $\mathrm{BW}$ gain. Optigen treatment increased $(\mathrm{P}<0.01)$ the digestibility of crude protein and neutral detergent fiber. Optigen treatment increased $(\mathrm{P}<0.01)$ estimated $\mathrm{N}$ balance, milk urea-N, and net energy (NE) for gain. Without affecting blood total protein, creatinine, urea-N, triglycerides, glucose, $\beta$-hydroxybutyrate, or non-esterified free fatty acids, Optigen treatment increased the concentrations of blood albumin and cholesterol compared to the control $(\mathbf{P}<\mathbf{0 . 0 5})$. In conclusion, slow-release urea could replace soybean meal in ruminant diets with no adverse effects on feed intake, nitrogen utilization, or digestibility; however, it improved the total tract digestibility of fiber and crude protein in cows.
\end{abstract}

Key words: milk production and composition, nitrogen metabolism, nitrogen balance, nitrogen excretion, slow-release urea

The protein nutrition of dairy cows is of great importance because of its direct influence on milk production, reproductive efficiency, and feeding cost. For many years, nonprotein nitrogen (NPN) products have been used to increase $\mathrm{N}$ concentration in the diet from cheap sources (Chumpawadee et al., 2006). Rumen microbes can effectively convert dietary $\mathrm{N}$ into microbial protein in ruminants. However, the capacity to convert NPN into microbial protein is limited because of the rapid hydrolysis of the $\mathrm{N}$ in the NPN feeds to ammonia $\left(\mathrm{NH}_{3}-\mathrm{N}\right)$ in the rumen (Joysowal et al., 2019). The rapid breakdown of NPN to $\mathrm{NH}_{3}-\mathrm{N}$ causes a loss of $\mathrm{NH}_{3}-\mathrm{N}$ especially at a faster rate of production than $\mathrm{NH}_{3}-\mathrm{N}$ utilization by the rumen bacteria, resulting in $\mathrm{NH}_{3}-\mathrm{N}$ toxicity at high concentration (Satter and Roffler, 1975). However, the slowrelease NPN compounds can be used as alternatives to NPN sources (El-Zaiat et al., 2014, 2020 a).

Slow-release urea would reduce $\mathrm{N}$ excretion in the rumen of the animal causing improved $\mathrm{N}$ utilization by rumen microbes without any adverse effects on nutrient digestion (Galo et al., 2003; El-Zaiat et al., 2020 a). The most common examples of slow-release urea are biuret, urea-formaldehyde, urea phosphate, or urea bound to sub- strates (Joysowal et al., 2019). The main disadvantage of slow-release NPN compounds is the loss of a substantial part of the NPN in the rumen without being converted to $\mathrm{NH}_{3}-\mathrm{N}$, resulting in reduced incorporation into microbial protein (Joysowal et al., 2019). Additionally, the incorporation of $\mathrm{NH}_{3}-\mathrm{N}$ in the microbial protein depends on the availability of energy, making the coordination between the rate of ammonia production in the rumen and the rate of carbohydrate digestion a critical issue for the maximum utilization of NPN sources (Chumpawadee et al., 2006). Lizarazo et al. (2014) evaluated the inclusion of two sources of slow-release urea with soluble carbohydrates in the diet of Pelibuey lambs and observed lowered ruminal $\mathrm{pH}$ and $\mathrm{NH}_{3}-\mathrm{N}$ without affecting the digestion of DM and neutral detergent fiber (NDF) or the rate of microbial protein synthesis. Furthermore, Cherdthong et al. (2011) observed a reduced in vitro ruminal $\mathrm{NH}_{3}-\mathrm{N}$ and increased cellulolytic bacterial population with urea calcium sulfate mixtures compared with urea. Recently, Gadegaonkar et al. (2019) observed that feeding slow-release urea at $1 \%$ level in concentrate mixture to lactating cows increased intakes, milk production, and contents of milk fat and protein without affecting the concentration 
of solids not fat, total solids, and total ash in milk, as well as improved nutrient digestibility. The objectives of this study were to evaluate the impact of feeding slow-release urea on $\mathrm{N}$ balance, nutrient digestion, milk production, and composition and blood metabolites of lactating Holstein cows. The hypothesis was that feeding slow-release urea will reduce $\mathrm{N}$ release in the rumen and improve $\mathrm{N}$ utilization by rumen microbes resulting in improved nutrient digestion and animal performance. Moreover, the experiment was conducted during the transition period which is characterized by a number of metabolic, endocrine, physiologic, and immune adaptations. The degree and length of this period could render cows more susceptible to poor productive and reproductive performance as well. Therefore, replacing soybean meal (SBM) with protein supplements rich in rumen undegradable protein diets during the transition period may assist dairy cows to manage extensive physiological changes, and improve production and $\mathrm{N}$ utilization.

\section{Material and methods}

\section{Study location}

The experiment was conducted at Lamar Dairy Farm, El-Noubaria, Behera Governorate (Egypt). The location is at latitude $30^{\circ} 44^{\prime} 13.20^{\prime \prime} \mathrm{N}$ and longitude $29^{\circ} 54^{\prime} 16.06^{\prime \prime}$ E. Samples were analyzed at the Animal and Fish Production Department, Faculty of Agriculture, Alexandria University (Egypt) and Dairy Science Department, National Research Centre (Egypt). All experimental cows were cared for and handled under established protocols approved and authorized by the Institutional Animal Care and Use Committee of the Alexandria University.

\section{Cows, feeding and management}

Three-hundred multiparous lactating Holstein cows ( $71 \pm 23.8$ days in milk) stratified by live body weight $(635 \pm 25 \mathrm{~kg})$, parity $(2.5 \pm 0.7)$, and previous milk production $(30.0 \pm 3.5 \mathrm{~kg} \mathrm{~d}-1)$ were randomly assigned to two treatments ( 150 cows per treatment). Milk production did not differ between the two groups before administering the slow-release urea treatment. Before starting the experiment, cows in each treatment were weighed on a digital multi-purpose platform scale 4 days after parturition as initial body weight (BW) and at 84 days of lactation as final BW, post-milking at 12:00 h. The cows were housed in two shaded barns (150 cows per barn), with free access to water, and they were fed two isonitrogenous and isocaloric total mixed rations (Table 1) formulated using the Gavish computer-operated cattle feeding system 2008 to meet the nutrient requirements of lactating cows according to the NRC (2001) recommendations. Adjustments were made to the diets to ensure the collection of orts.

The cows were fed diets with SBM and without slow-release urea (control treatment) or supplemented with $5.7 \mathrm{~g}$ slow-release urea (Optigen $1200^{\mathrm{TM}}$ Controlled Release Nitrogen; CPG Nutrients, Inc., Syracuse,
$\mathrm{NY}$ ) replacing $25 \mathrm{~g}$ of soya per $\mathrm{kg} \operatorname{diet} \mathrm{DM} \mathrm{CP}$ (Optigen treatment) for $84 \mathrm{~d}$. Optigen provides a high $\mathrm{N}$ concentration at $256 \% \mathrm{CP}(40.96 \mathrm{~N} \%)$. The experimental period lasted for 105 days, of which 21 days for treatment adaptation and 84 says for data and sampling collection. The diets were offered 6 times daily at 03:00, 05:00, 07:00, 11:00, 14:00, and 19:00 h. The TMR was prepared and distributed using a horizontal system mixer (DeLaval, Ontario, Canada) after mixing for $20 \mathrm{~min}$. Samples of feed were taken daily, composited weekly, dried at $60^{\circ} \mathrm{C}$ in a forced-air oven for $48 \mathrm{~h}$ (AOAC, 1997), and stored for chemical analysis. The nutrient contents of the feed ingredients are shown in Table 1. For each treatment, all cows were weighed on a digital multi-purpose platform scale at the beginning and end of the experiment.

Table 1. Ingredients and chemical composition of the total mixed ration fed to cows

\begin{tabular}{|c|c|c|}
\hline \multirow{2}{*}{ Items } & \multicolumn{2}{|c|}{ Diets $^{1}$} \\
\hline & control & Optigen \\
\hline \multicolumn{3}{|l|}{ Ingredients $(\mathrm{g} / \mathrm{kg}$ of $\mathrm{DM})$} \\
\hline corn silage & 163 & 170 \\
\hline green clover & 125 & 130 \\
\hline alfalfa hay & 112 & 114.3 \\
\hline wheat straw & 20 & 25 \\
\hline ground yellow corn & 245 & 245 \\
\hline flecked yellow corn & 28 & 28 \\
\hline soybean meal & 100 & 75 \\
\hline linseed meal & 55 & 55 \\
\hline gluten feed & 34 & 34 \\
\hline molasses & 25 & 25 \\
\hline sugar beet pulp meal & 30 & 30 \\
\hline distiller's dried grains with solubles & 20 & 20 \\
\hline slow-release urea (Optigen $1200^{\mathrm{TM}}$ ) & 0 & 5.7 \\
\hline Megalac & 30 & 30 \\
\hline sodium bicarbonate & 1.5 & 1.5 \\
\hline limestone & 6 & 6 \\
\hline mono calcium phosphate & 1.2 & 1.2 \\
\hline sodium chloride & 1.3 & 1.3 \\
\hline vitamins and minerals mixture $^{2}$ & 3 & 3 \\
\hline \multicolumn{3}{|l|}{ Chemical composition (g/kg of DM) } \\
\hline organic matter & 928 & 926 \\
\hline crude protein & 172 & 171 \\
\hline ether extract & 50 & 49 \\
\hline non-fiber carbohydrates ${ }^{3}$ & 394 & 392 \\
\hline neutral detergent fiber & 312 & 314 \\
\hline acid detergent fiber & 185 & 186 \\
\hline metabolisable energy (Mcal/kg DM) & 2.75 & 2.79 \\
\hline
\end{tabular}

${ }^{1}$ Diet: basal total mixed ration diet without Optigen; Optigen: basal TMR diet with replacing $25 \mathrm{~g}$ soybean meal with $27 \mathrm{~g}$ Optigen $1200^{\mathrm{TM}}$.

${ }^{2}$ Each one kg consists of 90000000 IU Vit. A, 2500000 IU Vit.D, 35000 $\mathrm{mg}$ Vit. E, carrying up to $1 \mathrm{~kg}, 40 \mathrm{~g}$ Magnesium, $0.400 \mathrm{~g}$ iodide, $15 \mathrm{~g}$ Copper, $0.150 \mathrm{~g}$ Cobalt, $50 \mathrm{~g}$ Zinc, $0.200 \mathrm{~g}$ Selenium, carrier on calcium carbonate, produced by Multi vita Company, Egypt.

${ }^{3}$ Non-structural carbohydrates calculated by difference $[1000-(\mathrm{NDF}$, $\mathrm{g} / \mathrm{kg}+\mathrm{CP}, \mathrm{g} / \mathrm{kg}+\mathrm{EE}, \mathrm{g} / \mathrm{kg}+\mathrm{ash}, \mathrm{g} / \mathrm{kg})]$. 


\section{Nutrient intake and digestibility}

Feed intake was recorded daily (the same cows used in the digestibility trials) by weighing the total daily amount of feed offered and the total daily amount of weighedback orts. In the 4th, 8 th, and 12 th week, nutrient digestibility trials were conducted, in which acid insoluble ash was used as an internal indigestibility marker (Sales and Janssens, 2003). Acid-insoluble ash contents of feeds and feces were used as an internal marker to estimate the apparent digestibility coefficients. For the digestibility trial, fecal grab samples (150-200 g each) were collected from 50 cows per treatment (for the same cows throughout the sampling period) twice daily at 09:00 and 16:00 h, dried at $60^{\circ} \mathrm{C}$ for $48 \mathrm{~h}$ in a forced-air oven and pooled.

The dried feed, orts, and fecal samples were ground to pass a 1-mm screen using a Wiley mill grinder and analyzed for dry matter (DM; method ID 930.15), ash (method ID 942.05), crude protein (CP; method ID 954.01) and ether extract (EE; method ID 920.39) according to the AOAC (1997) official methods. Sequential analyses of neutral detergent fiber (NDF) and acid detergent fiber (ADF) were performed by the procedure of Van Soest et al. (1991) using an Ankom ${ }^{200}$ Fiber Analyzer unit (ANKOM Technology Corporation, Macedon, NY, USA) with the use of alpha-amylase and sodium sulphite and expressed exclusive of residual ash. Concentration of dietary non-fiber carbohydrates (NFC, g/ kg) was calculated as $1000=(\mathrm{NDF}(\mathrm{g} / \mathrm{kg})+\mathrm{CP}(\mathrm{g} / \mathrm{kg})+\mathrm{EE}(\mathrm{g} / \mathrm{kg})$ $+\operatorname{ash}(\mathrm{g} / \mathrm{kg}))$.

\section{Sampling and analysis of blood plasma}

On the last day of the 4th, 8th, and 12th weeks of the experiment, $5 \mathrm{~mL}$ of blood samples were taken before the morning feeding at 03:00 $\mathrm{h}$ from the coccygeal vein of 50 cows from each treatment (the same cows used in the digestibility trials) into 5-mL heparinized tubes (Vacutainer, Becton Dickinson, Franklin Lakes, NJ). The blood samples were centrifuged at 2,000 $\times g$ for $15 \mathrm{~min}$ at room temperature. The plasma was separated into $2 \mathrm{~mL}$ Eppendorf tubes and frozen at $-20^{\circ} \mathrm{C}$ until analysis.

The blood plasma samples were analyzed to determine the concentration of total protein, albumin, blood urea-N (BUN), creatinine, glucose, triglycerides, and cholesterol. Biochemical blood constituents were measured colorimetrically using commercial colorimetric kits (SPINREACT, Ctra. Santa Coloma, 7, Girona, Spain). The concentration of plasma $\beta$-hydroxybutyrate (BHBA) was determined following the kinetic enzymatic method using a commercial kit (RANBUT D-3-hydroxybutyrate, Randox, Crumlin, Antrim, UK) while, plasma non-esterified free FA (NEFA) concentration was measured using a Randox commercial kit (Randox Crumlin, Antrim, UK). The globulin concentration was calculated by subtracting the albumin values from their corresponding total protein values.

\section{Milk sampling and composition}

The cows were machine milked (DeLaval parallel parlour Tumba, Sweden) three times daily at 04:00,
12:00, and 20:00 h, and samples ( $30 \mathrm{~g} \mathrm{~kg}^{-1}$ of milk yield) were collected at each milking. For each cow, a mixed sample (1 per cow) of milk (proportional to amounts produced in each milking time) was taken daily every two weeks to determine the milk composition. The milk samples were analyzed using infrared spectrophotometry (EKOMILK-M ultrasonic milk analyzer, EON Trading 2000, INC, Bulgaria). Milk urea nitrogen (MUN) was measured using commercial colorimetric kits (SPINREACT, Ctra. Santa Coloma, 7, Girona, Spain). For each collection period, the average yield (g/day) of individual milk component was calculated for each cow by multiplying milk yield by the component content $(\mathrm{g} / \mathrm{kg})$ of milk.

The gross energy content was calculated according to Tyrrell and Reid (1965). The milk energy output $(\mathrm{Mcal} / \mathrm{d})$ was calculated as milk energy $(\mathrm{Mcal} / \mathrm{kg}) \times$ milk yield $(\mathrm{kg} / \mathrm{d})$. Fat corrected milk (FCM, kg/day) was calculated as $0.4 \times$ milk yield $(\mathrm{kg} /$ day $)+15 \times$ fat yield $(\mathrm{kg} /$ day) and energy-corrected milk (ECM, kg/day) as (0.327 $\times$ milk yield $(\mathrm{kg} /$ day $)+12.95 \times$ fat yield $(\mathrm{kg} /$ day $)+7.2 \times$ protein yield (kg/day), both according to Tyrrell and Reid (1965). Feed efficiency was calculated and expressed as milk yield, FCM, and ECM per unit of DMI.

Body weight measurement, estimated nitrogen balance, and net energy (NE)

As previously noted, individual cows were weighed at the beginning and at the end of the experiment. These weights were used to calculate the mean BW changes of cows for each experimental period. Estimated NEL / $\mathrm{kg}$ was calculated by total net energy (maintenance, BW gain, and milk) divided by DMI according to Neal et al. (2014).

The concentration of net energy for lactation (NEL; $\mathrm{Mcal} / \mathrm{kg}$ ) in milk was calculated according to NRC $(2001)$ as milk yield $\times(0.0929 \times$ fat $\% \times 0.0547 \times$ protein $\% \times 0.0395 \times$ lactose $\%$ ). Urinary nitrogen was predicted using the following equation as $0.026 \times \mathrm{MUN}(\mathrm{mg} / 100$ $\mathrm{mL}) \times \mathrm{BW}, \mathrm{kg}$ according to Wattiaux and Karg (2004). Fecal $\mathrm{N}$ excretion $(\mathrm{g} / \mathrm{d})$ was calculated using the following equation: $\mathrm{N}$ intake $(\mathrm{g} / \mathrm{d})$ - urinary $\mathrm{N}$ excretion $(\mathrm{g} / \mathrm{d})$ - milk N (g/d). Nitrogen balance was calculated as N intake - fecal $\mathrm{N}$ - urinary $\mathrm{N}-$ milk N. Milk N was determined as milk protein divided by 6.38 . NE for maintenance $\left(\mathrm{Mcal} /\right.$ day) was calculated as $\mathrm{BW}^{0.75} \times 0.08(\mathrm{NRC}$, 2001). Energy of BW change was assumed to be 5.114 $\mathrm{Mcal} / \mathrm{kg}$ of gain or $4.924 \mathrm{Mcal} / \mathrm{kg}$ of loss (NRC, 2001). Energy partitioning was determined during treatment periods using data of milk yield, milk composition, and BW of experimental animals.

\section{Statistical analyses}

Data were analyzed as a completely randomized design with repeated measures using the PROC MIXED procedure of SAS 9.4, 2020 (SAS Inst. Inc. Cary, NC, USA) with week as repeated measures. The individual cow was the experimental unit. Data for variables measured daily for each week were averaged before statisti- 
cal analyses. The statistical model included the effects of treatment, week, and treatment $\times$ week interactions. Animals nested within treatments were considered a random effect, whereas the treatment was considered the fixed effect. Two covariance structures were considered in the REPEATED statement in PROC MIXED: compound symmetry (cs) and auto-regressive AR (1). The error structure with the lowest Akaike information criteria fit statistic was selected for the model. When the treatment $F$-test was significant at $\mathrm{P}<0.05$, the means were compared by applying the probability of different option of the least-squares means statement.

\section{Results}

Feeding slow-release urea did not affect feed intake (Table 2) without affecting the digestibility of OM, EE, NSC, and ADF, while increased $(\mathrm{P}<0.01)$ the digestibility of CP and NDF (Table 2).
Cows fed slow-release urea showed a greater $(\mathrm{P}<0.01)$ estimated $\mathrm{N}$ balance and MUN compared to the control (Table 3). Optigen did not affect milk N, urinary N excretion, fecal $\mathrm{N}$ excretion, and urinary $\mathrm{N} /$ fecal $\mathrm{N}$ (Table 3 ). Feeding Optigen increased $(\mathrm{P}<0.01) \mathrm{NE}$ for gain compared to the control.

No differences were observed between treatments for initial and final body weights (Table 4); however, the Optigen feeding increased $(\mathrm{P}<0.001)$ total weight gain and daily weight gain. Treatments did not affect daily milk production (milk, ECM, and FCM), yields of milk components, or feed efficiency (Table 4).

Optigen treatments did not affect the concentrations of blood total protein, creatinine, urea-N, triglycerides, glucose, NEFA, and BHBA (Table 5). However, Optigen feeding increased the concentrations of blood albumin $(\mathrm{P}=0.019)$ and cholesterol $(\mathrm{P}<0.001)$ compared to the control.

Table 2. Intake and nutrient digestibility ( $\mathrm{g}$ digested/kg ingested DM) of lactating Holstein dairy cows fed with slow-release urea $(\mathrm{n}=50$ cow/ treatment)

\begin{tabular}{|c|c|c|c|c|c|c|}
\hline & \multicolumn{2}{|c|}{ Diets $^{1}$} & \multirow{2}{*}{ SEM } & \multicolumn{3}{|c|}{ P-value } \\
\hline & control & Optigen & & diet & time & diet $\times$ time \\
\hline Intake $(\mathrm{kg} / \mathrm{d})$ & 18.6 & 19.2 & 0.12 & 0.501 & $<0.001$ & 0.001 \\
\hline \multicolumn{7}{|l|}{ Digestibility } \\
\hline organic matter & 655 & 665 & 7.9 & 0.423 & 0.598 & 0.928 \\
\hline crude protein & 627 & 656 & 2.6 & $<0.001$ & 0.253 & 0.638 \\
\hline ether extract & 581 & 587 & 9.6 & 0.668 & 0.187 & 0.449 \\
\hline non-fiber carbohydrates & 732 & 729 & 14.3 & 0.906 & 0.945 & 0.157 \\
\hline neutral detergent fiber & 543 & 587 & 7.5 & 0.003 & 0.104 & 0.286 \\
\hline acid detergent fiber & 454 & 462 & 3.7 & 0.176 & 0.769 & 0.665 \\
\hline
\end{tabular}

${ }^{1}$ Diet: basal total mixed ration diet without Optigen; Optigen: basal TMR diet with replacing $25 \mathrm{~g}$ soybean meal with $27 \mathrm{~g}$ Optigen $1200^{\mathrm{TM}}$.

Table 3. Nitrogen balance and calculated values of net energy of lactating Holstein dairy cows fed with slow-release urea $(\mathrm{n}=50$ cow/treatment)

\begin{tabular}{|c|c|c|c|c|c|c|}
\hline & \multicolumn{2}{|c|}{ Diets $^{1}$} & \multirow{2}{*}{ SEM } & \multicolumn{3}{|c|}{ P-value } \\
\hline & control & Optigen & & diet & time & diet $\times$ time \\
\hline 1 & 2 & 3 & 4 & 5 & 6 & 7 \\
\hline \multicolumn{7}{|l|}{ Nitrogen balance } \\
\hline $\mathrm{N}$ intake $(\mathrm{g} / \mathrm{d})$ & 512 & 529 & 6.2 & 0.361 & $<0.001$ & 0.001 \\
\hline milk N (g/d) & 179 & 179 & 2.7 & 0.984 & 0.598 & 0.773 \\
\hline urinary $\mathrm{N}$ excretion $(\mathrm{g} / \mathrm{d})$ & 226 & 226 & 1.0 & 0.727 & 0.774 & 0.992 \\
\hline fecal $N$ excretion (g/d) & 114 & 113 & 1.0 & 0.727 & 0.774 & 0.992 \\
\hline urinary $\mathrm{N} /$ fecal $\mathrm{N}$ & 2.00 & 2.01 & 0.021 & 0.626 & 0.829 & 0.991 \\
\hline Nitrogen balance (g/d) & -6.44 & 10.06 & 3.008 & 0.001 & 0.001 & $<0.001$ \\
\hline milk urea-N (mg/dl) & 15.3 & 17.2 & 0.21 & $<0.001$ & 0.052 & 0.034 \\
\hline \multicolumn{7}{|c|}{ Calculated net energy (NE) values (Mcal/d) } \\
\hline NE maintenance & 10.1 & 10.12 & 0.033 & 0.961 & 0.772 & 0.982 \\
\hline NE gain & 0.41 & 0.49 & 0.013 & $<0.001$ & 0.876 & 0.698 \\
\hline NE milk & 22.2 & 21.9 & 0.28 & 0.405 & 0.313 & 0.661 \\
\hline total NE & 32.7 & 32.5 & 0.28 & 0.518 & 0.330 & 0.662 \\
\hline
\end{tabular}


Table 3 - contd

\begin{tabular}{l|c|c|c|ccc}
\hline \multicolumn{1}{c|}{1} & 2 & 3 & 4 & 5 & 6 & 7 \\
\hline NE lactation (Mcal/kg DM intake) & 1.77 & 1.69 & 0.015 & 0.002 & 0.016 \\
NE partitioning (\% of NE) & & & & & \\
NE maintenance & 31.2 & 31.3 & 0.29 & 0.765 & 0.448 \\
NE gain & 1.26 & 1.50 & 0.041 & $<0.001$ & 0.685 \\
NE milk & 67.6 & 67.2 & 0.304 & 0.403 & 0.417 & 0.749 \\
\hline
\end{tabular}

${ }^{1}$ Diet: basal total mixed ration diet without Optigen; Optigen: basal TMR diet with replacing $25 \mathrm{~g}$ soybean meal with $27 \mathrm{~g}$ Optigen $1200^{\mathrm{TM}}$.

MUN: milk urea nitrogen.

Table 4. Milk yield and composition, and growth of lactating Holstein dairy cows fed with slow-release urea $(\mathrm{n}=150 \mathrm{cow} / \mathrm{treatment})$

\begin{tabular}{|c|c|c|c|c|c|c|}
\hline & \multicolumn{2}{|c|}{$\operatorname{Diets}^{1}$} & \multirow{2}{*}{ SEM } & \multicolumn{3}{|c|}{ P-value } \\
\hline & control & Optigen & & diet & time & diet $\times$ time \\
\hline \multicolumn{7}{|l|}{ Body weight } \\
\hline initial body weight (kg) & 635.2 & 635.4 & 2.74 & 0.972 & - & - \\
\hline final body weight (kg) & 641.9 & 643.3 & 2.72 & 0.727 & - & - \\
\hline body weight change (kg) & 6.72 & 7.93 & 0.205 & $<0.001$ & 0.876 & 0.698 \\
\hline daily weight change (g/d) & 80.1 & 94.4 & 2.44 & $<0.001$ & 0.876 & 0.698 \\
\hline \multicolumn{7}{|l|}{ Yield $(\mathrm{kg} / \mathrm{d})$} \\
\hline milk & 31.9 & 32.3 & 0.38 & 0.457 & 0.949 & 0.940 \\
\hline energy-corrected milk (ECM) & 33.2 & 32.6 & 0.31 & 0.180 & 0.168 & 0.757 \\
\hline fat-corrected milk (FCM) & 29.5 & 28.9 & 0.38 & 0.345 & 0.317 & 0.599 \\
\hline fat & 1.11 & 1.07 & 0.017 & 0.055 & 0.098 & 0.357 \\
\hline protein & 1.14 & 1.14 & 0.017 & 0.996 & 0.598 & 0.789 \\
\hline lactose & 1.38 & 1.40 & 0.018 & 0.429 & 0.646 & 0.347 \\
\hline \multicolumn{7}{|l|}{ Milk composition $(\%)$} \\
\hline fat & 3.48 & 3.31 & 0.030 & 0.111 & 0.009 & 0.088 \\
\hline protein & 3.58 & 3.54 & 0.032 & 0.346 & 0.463 & 0.413 \\
\hline lactose & 4.32 & 4.32 & 0.030 & 0.985 & 0.245 & 0.070 \\
\hline \multicolumn{7}{|l|}{ Efficiency } \\
\hline milk yield/DMI & 1.72 & 1.68 & 0.018 & 0.099 & 0.007 & 0.006 \\
\hline ECM yield/DMI & 1.79 & 1.69 & 0.016 & 0.231 & 0.096 & 0.011 \\
\hline FCM yield/DMI & 1.59 & 1.50 & 0.019 & 0.102 & 0.336 & 0.100 \\
\hline
\end{tabular}

${ }^{1}$ Diet: basal total mixed ration diet without Optigen; Optigen: basal TMR diet with replacing $25 \mathrm{~g}$ soybean meal with $27 \mathrm{~g}$ Optigen $1200^{\mathrm{TM}}$.

Table 5. Blood measurements $(\mathrm{mg} / \mathrm{dL})$ of lactating Holstein dairy cows fed with slow-release urea $(\mathrm{n}=50 \mathrm{cow} / \mathrm{treatment})$

\begin{tabular}{|c|c|c|c|c|c|c|}
\hline & \multicolumn{2}{|c|}{ Diets $^{1}$} & \multirow{2}{*}{ SEM } & \multicolumn{3}{|c|}{ P-value } \\
\hline & control & Optigen & & diet & time & diet $\times$ time \\
\hline Total protein & 6.98 & 7.14 & 0.126 & 0.373 & 0.100 & 0.460 \\
\hline Albumin & 2.87 & 3.32 & 0.126 & 0.019 & 0.205 & 0.857 \\
\hline Creatinine & 1.75 & 1.81 & 0.090 & 0.658 & 0.183 & 0.490 \\
\hline Blood urea nitrogen & 14.8 & 15.4 & 0.42 & 0.370 & 0.849 & 0.077 \\
\hline Triglycerides & 67.8 & 63.2 & 3.84 & 0.402 & 0.252 & 0.513 \\
\hline Cholesterol & 78.8 & 112.7 & 4.74 & $<0.001$ & 0.676 & 0.641 \\
\hline Glucose & 68.3 & 69.1 & 1.22 & 0.655 & 0.129 & 0.218 \\
\hline Non-esterified fatty acids (mmol/L) & 0.61 & 0.62 & 0.013 & 0.775 & 0.526 & 0.474 \\
\hline$\beta$-hydroxybutyrate $(\mathrm{mmol} / \mathrm{L})$ & 0.59 & 0.58 & 0.010 & 0.390 & 0.963 & 0.342 \\
\hline
\end{tabular}

${ }^{1}$ Diet: basal total mixed ration diet without Optigen; Optigen: basal TMR diet with replacing $25 \mathrm{~g}$ soybean meal with $27 \mathrm{~g}$ Optigen $1200^{\mathrm{TM}}$. 


\section{Discussion}

The Optigen treatment did not affect feed intake indicating unaffected palatability, which could be due to the isonitrogenous and isocaloric fed diets (Santiago et al., 2015). Galo et al. (2003) and Salami et al. (2020) did not observe any effects on feed intake with feeding slow-release urea to animals. The high fiber content of the silage used, and high NDF values can interfere with feed intake and consequently influence the rates of consumption (Van Soest, 1994). However, increased (Gadegaonkar et al., 2019) or decreased (Miranda et al., 2019) feed intake was observed with slow-release urea feeding to lactating cows. The used products of slow-release urea, diet composition, and diet contents of non-nitrogen protein and fermentable carbohydrates, animal physiological stage, and other factors may explain the differences between experiments (Salami et al., 2020).

Optigen treatment did not affect the digestibility of OM, EE, NSC, and ADF, which may be a consequence of unaffected DM intake and feed consumption. Optigen increased the digestibility of CP by $4.6 \%$ and NDF by $8 \%$, which could be due to the ability of slow-release urea to increase fiber digesting microorganisms and cellulolytic bacterial population due to continuous supply of $\mathrm{N}$ in the rumen, which in turn improved ruminal microbial balance (Cherdthong et al., 2011). The supplementation with slow-release urea source could provide continuous $\mathrm{NH}_{3}-\mathrm{N}$ for microbial growth (Leng and Nolan, 1984). Galo et al. (2003) observed increased total tract apparent $\mathrm{DM}$ and $\mathrm{CP}$ digestibilities and lowered apparent ADF digestibility without affecting OM, NDF, starch, sugar, and NSC when lactating cows were fed diet containing Optigen. Additionally, Lizarazo et al. (2014) observed that feeding slow-release urea to lambs did not affect DM intake or total tract digestibility. Recently, Gadegaonkar et al. (2019) observed increased digestibility of DM, OM, $\mathrm{CP}, \mathrm{EE}, \mathrm{NSC}, \mathrm{NDF}$, and ADF with feeding lactating cows on diets containing slow-release urea.

The minimal effects of Optigen on estimated milk $\mathrm{N}$, urinary $\mathrm{N}$ excretion, fecal $\mathrm{N}$ excretion, or urinary $\mathrm{N} / \mathrm{fe}$ cal $\mathrm{N}$ indicate the ability of ruminants to recycle $\mathrm{N}$ to compensate for differences in the release time of $\mathrm{N}$ in the rumen (Reynolds and Kristensen, 2008). Marini and Van Amburgh (2005) reported that increasing urinary N excretion reflected the overfeeding of degradable $\mathrm{N}$ in the rumen. In the current study, feeding cows on slowrelease urea compared to the SBM diet may have resulted in differences in ruminal $\mathrm{NH}_{3}-\mathrm{N}$ levels, however, this variable was not measured. Whilst, the absence effect of Optigen compared with SBM diet on estimated urinary $\mathrm{N}$ excretion was assumed to be due to the slower-release properties. Moreover, these results revealed that the Optigen diet demonstrated an effective form for releasing $\mathrm{N}$ slowly in comparison to SBM, which leads to mitigate rapid ruminal $\mathrm{NH}_{3}-\mathrm{N}$ release and subsequent effects on $\mathrm{N}$ utilization and sequestration (BUN and MUN, fecal and urinary $\mathrm{N}$ excretion) and glucose metabolism. Both BUN and MUN were positively linked, which might be due to the passive diffusion of urea from blood to milk (Clark et al., 1977). However, our results showed that the MUN level did not fit with the unaffected BUN, urine, and fecal $\mathrm{N}$ excretion. The variation in MUN between treatment and lactation periods could be due to the feeding regime and schedule followed throughout the experiment (Roy et al., 2005). The BUN and MUN varied throughout the day as a consequence of feeding time and frequencies (Rodriguez et al., 1997).

The lacking effect on BUN confirmed the reported result of Van Soest (1994) that decreasing BUN concentrations is usually combined with a decline in ruminal $\mathrm{NH}_{3}-\mathrm{N}$ release to the bloodstream and may have led to a slower release of urea from the Optigen diet. Increased $\mathrm{CP}$ digestibility by $4.6 \%$ means decreases in fecal $\mathrm{N}$ excretion relative to $\mathrm{N}$ intake. Typically, this is explained by higher absorption of rumen degradable $\mathrm{N}$ as ammonia from the forestomach that is excreted in urine (Marini and Van Amburgh, 2005). From the environmental point of view, feeding a slow-release urea diet could be capable of switching $\mathrm{N}$ excretion away from urine, reflecting minimal environmental pollution justified by a minimal effect on $\mathrm{N}$ excretion. Optigen treatment increased the estimated $N$ balance by $256 \%$ and MUN by $12.4 \%$. Similar results were observed by Galo et al. (2003) who noted that Optigen inclusion in the diet of lactating cows did not affect the calculated $\mathrm{N}$ balance or urinary $\mathrm{N}$ excretion; however, increased MUN. Lizarazo et al. (2014) stated that feeding slow-release urea to lambs did not affect the urinary and fecal $\mathrm{N}$ excretion or the $\mathrm{N}$ retained. The current differences in $\mathrm{N}$ balance and MUN values may be positively associated with the basal diet ingredients used in each experimental diet. In the present study, no differences were detected in response to milk protein content and throughout the different feeding periods, although milk urea concentration was significantly influenced between Optigen and SBM diets. Urea N concentration in blood and milk reflects not only the CP degradation in the rumen but also post-ruminal protein metabolism (Roy et al., 2005), while milk protein content mainly correlates and responds to energy intake in the diet and ruminal microbial CP production (Hwang et al., 2000). Thus, the lacking effect on milk protein content may be ascribed to the balanced protein and energy ratio in the experimental diets.

The increase in estimated $\mathrm{N}$ balance could be also explained by the increased $\mathrm{N}$ availability due to the increased digestibility of the diet, driven by a slow-release urea diet, which leads to an increased energy and protein synchronization of protein deposition, which is evidenced by the increased BW gain. However, increased MUN by $12.4 \%$ with a slow-release urea diet could be due to efficient utilization of degradable $\mathrm{N}$ by rumen microorganisms. Otherwise, the dietary SBM may have participated and provided some growth factors such as amino acids, peptides, and nucleotides to the ruminal microbes indicating higher $\mathrm{N}$ utilization (Dehority, 2003). 
Inostroza et al. (2010) indicated that Optigen supplementation to lactating cows increased microbial growth and led to $6 \%$ more $\mathrm{N}$ in milk. Mulet (2009) suggested that higher MUN indicates increased dietary $\mathrm{N}$, ruminal degradable or undegradable protein.

Optigen treatment increased estimated NE for gain by $19.5 \%$. Values of BW gain and total NE were increased due to the inclusion of slow-release urea in the diet, while NE partitioned into maintenance and milk were similar between dietary treatments. These findings revealed that cows fed a slow-release urea diet shifted more NE into BW compared with those fed the SBM diet. According to Taylor and Allen (2005), energy utilization is mainly affected by the stage of lactation and milk production which is mostly affected by mammary gland capacity, hormone secretion, insulin resistance of tissues. In the current study, the shift in NE utilization toward BW associated with unaffected DMI as a result of feeding a slow-release urea diet indicates that the latter had a favorable amount of NE that was partitioned toward body tissue during early lactation with a slight depression in milk energy (El-Zaiat et al., 2020 b). The mechanism whereby the inclusion of slow-release urea in the diet increased the NE for gain but not for milk is difficult to be explained.

Optigen treatment increased total weight gain and daily weight gain by about $18 \%$, which may be the result of improved $\mathrm{N}$ utilization by ruminal microflora and improved digestion of fibers and CP (Gadegaonkar et al., 2019). In their meta-analysis, Salami et al. (2020) indicated that improving ruminal microbial CP is expected to increase the metabolizable protein supply and, therefore, enhance the production performance of ruminants. Gadegaonkar et al. (2019) stated that the supplementation of slow-release urea compound might have resulted in the multiplication of digesters in the rumen due to continuous supply of nitrogen, resulting in improved feed utilization and daily gain.

Optigen treatment did not affect daily milk production, milk composition, or milk (feed) efficiency. Galo et al. (2003) and Miranda et al. (2019) observed that feeding slow-release urea to lactating cows did not affect milk production, milk contents of fat, or milk true protein percentage. However, Gadegaonkar et al. (2019) observed increased milk production with slow-release urea feeding to lactating cows. Tedeschi et al. (2002) observed a lowered feed intake and unaffected milk production with the supplementation with polymer-coated slow urea (Optigen 1200) resulting in improved feed efficiency.

According to Tye et al. (2017), improved feed digestion is one of the most important factors affecting dairy efficiency. The unaffected nutrients digestibility may contribute to similar milk production, and subsequently could be responsible for similar dairy efficiency.

In the current study, it is also possible that changes in nutrients intake and digestibility would alter the blood biochemical attributes concentrations. Therefore, the absence of differences in nutrients intake and digestibility may explain the lack of differences in biochemical attributes concentrations among dietary treatments. Treatments did not affect the concentrations of blood total protein, creatinine, urea-N, triglycerides, glucose, NEFA, and BHBA; however, increased the concentrations of blood albumin and cholesterol. These results indicate improved $\mathrm{N}$ utilization and absence of body fat mobilization. The reason for the increased cholesterol is unclear.

In conclusion, the results showed that feeding slowrelease urea did not affect feed intake or digestibility; however, improved the total tract digestibility of fiber and crude protein in cows. Moreover, there was no clear difference in $\mathrm{N}$ utilization by the cow. Therefore, the use of slow-release urea as a protein replacement is attractive in ruminant diets because of its low cost compared with other protein feeds such as soybean meal with high rumen degradability.

\section{Acknowledgments}

The authors gratefully acknowledge the Lamar dairy farm staff and workers for their facilities, support, and assistance during the experimental periods. The authors are immensely grateful to all laboratory assistants for their technical support in the laboratory.

\section{References}

AOAC (1997). Official Methods of Analysis, 16th ed. Association of Official Analytical Chemists, Washington, DC, USA.

Cherdthong A., Wanapat M., Wachirapakorn C. (2011). Effects of urea-calcium mixture in concentrate containing high cassava chip on feed intake, rumen fermentation and performance of lactating dairy cows fed on rice straw. Livest. Sci., 136: 76-84.

Chumpawadee S., Sommart K., Vongpralub T., Pattarajinda V. (2006). Effects of synchronizing the rate of dietary energy and nitrogen release on ruminal fermentation, microbial protein synthesis, blood urea nitrogen and nutrient digestibility in beef cattle. AsianAustralas. J. Anim. Sci., 19: 181-188.

Clark J.H., Spires H.R., Derrig R.G., Bennink M.R. (1977). Milk production, nitrogen utilization and glucose synthesis in lactating cows infused postruminally with sodium caseinate and glucose. J. Nutr., 107: 631-644.

Dehority B.A. (2003). Rumen microbiology (Russell). Nottingham University Press, Nottingham, NG11 OAX, UK.

El-Zaiat H.M., Araujo R.C., Soltan Y.A., Morsy A.S., Louvandini H., Pires A.V., Patino H.O., Correa P.S., Abdalla A.L. (2014). Encapsulated nitrate and cashew nut shell liquid on blood and rumen constituents, methane emission, and growth performance of lambs. J. Anim. Sci., 92: 2214-2224.

El-Zaiat H.M., Araujo R.C., Louvandini H., Patiño H.O., Abdalla A.L. (2020 a). Effects of dietary replacement of urea with encapsulated nitrate and cashew nut shell liquid on nutrient digestibility, nitrogen balance, and carcass characteristics in growing lambs. Anim. Feed Sci. Technol., 266: 114515.

El-Zaiat H.M., Mohamed D.A., Sallam S.M.A. (2020 b). Palmitic acid-enriched fat supplement alleviates negative production responses in early lactation period of Holstein dairy cows. Anim. Prod. Sci., 60: 1598-1606.

Gadegaonkar G., Gulavane S., Karamble N. (2019). Influence of slow release non-protein nitrogen compound on utilization of poor quality roughages and lactation performance in lactating cows. Int. J. Livest. Res., 9. https://doi.org/10.5455/ijlr.20180720071909 
Galo E., Emanuele S.M., Sniffen C.J., White J.H., Knapp J.R. (2003). Effects of a polymer-coated urea product on nitrogen metabolism in lactating Holstein dairy cattle. J. Dairy Sci., 86: 2154-2162.

Hwang S.Y., Lee M.J., Chiou P.W.S. (2000). Monitoring nutritional status of dairy cows in Taiwan using milk protein and milk urea nitrogen. Asian-Australas. J. Anim. Sci., 13: 1667-1673.

Inostroza J.F., Shaver R.D., Cabrera V.E., Tricárico J.M. (2010). Effect of diets containing a controlled-release urea product on milk yield, milk composition, and milk component yields in commercial Wisconsin dairy herds and economic implications. Prof. Anim. Sci., 26: $175-180$.

Joysowal M., Tyagi A.K., Tyagi N., Kumar S., Keshri A. (2019). Use of slow release ammonia products in ruminant diet: A review. J. Entomol. Zool. Stud., 7: 882-888.

Leng R.A., Nolan J.V. (1984). Nitrogen metabolism in the rumen. J. Dairy Sci., 67: 1072-1089.

Lizarazo A.C., Mendoza G.D., Kú J., Melgoza L.M., Crosby M. (2014). Effects of slow-release urea and molasses on ruminal metabolism of lambs fed with low-quality tropical forage. Small Rumin. Res., 116: 28-31.

Marini J.C., Van Amburgh M.E. (2005). Partition of nitrogen excretion in urine and the feces of Holstein replacement heifers. J. Dairy Sci., 88: 1778-1784.

Miranda M.S., Arcaro J.R.P., Saran Netto A., Silva S.L., Pinheiro M.G., Leme P.R. (2019). Effects of partial replacement of soybean meal with other protein sources in diets of lactating cows. Animal, 13: 1403-1411.

Mulet J.F.I. (2009). Evaluation of Optigen ${ }^{\circledR}$ use in commercial dairy herd diets. M.S. Thesis, University of Wisconsin-Madison.

Neal K., Eun J.S., Young A.J., Mjoun K., Hall J.O. (2014). Feeding protein supplements in alfalfa hay-based lactation diets improves nutrient utilization, lactational performance, and feed efficiency of dairy cows. J. Dairy Sci., 97: 7716-7728.

NRC (2001). Nutrient Requirements of Dairy Cattle, 7th ed. National Academies Press, D.C., USA. https://doi.org/10.17226/9825

Reynolds C.K., Kristensen N.B. (2008). Nitrogen recycling through the gut and the nitrogen economy of ruminants: an asynchronous symbiosis. J. Anim. Sci., 86: E293-305.

Rodriguez L.A., Stallings C.C., Herbein J.H., McGilliard M.L. (1997). Diurnal variation in milk and plasma urea nitrogen in Holstein and
Jersey cows in response to degradable dietary protein and added fat. J. Dairy Sci., 80: 3368-3376.

Roy B., Mehla R.K., Sirohi S.K. (2005). Effect of dietary feeding regimens on urea and protein concentration of milk in Murrah buffaloes. Asian-Australas. J. Anim. Sci., 18: 973-979.

Salami S.A., Moran C.A., Warren H.E., Taylor-Pickard J. (2020). A meta-analysis of the effects of slow-release urea supplementation on the performance of beef cattle. Animals, 10: 657.

Sales J., Janssens G.P.J. (2003). Acid-insoluble ash as a marker in digestibility studies: A review. J. Anim. Feed Sci., 12: 383-401.

Santiago B.T., Villela S.D.J., de Paula Leonel F., Zervoudakis J.T., Araújo R.P., Machado H.V.N., Moreira L.M., de Oliveira T.S. (2015). Slow-release urea in diets for lactating crossbred cows. Rev. Bras. Zootec., 44: 193-199.

Satter L.D., Roffler R.E. (1975). Nitrogen Requirement and Utilization in Dairy Cattle. J. Dairy Sci., 58: 1219-1237.

Taylor C.C., Allen M.S. (2005). Corn grain endosperm type and brown midrib 3 corn silage: Feeding behavior and milk yield of lactating cows. J. Dairy Sci., 88: 1425-1433.

Tedeschi L.O., Baker M.J., Ketchen D.J., Fox D.G. (2002). Performance of growing and finishing cattle supplemented with a slowrelease urea product and urea. Can. J. Anim. Sci., 82: 567-573.

Tye B.M., Yang S.Y., Eun J.S., Young A.J., Hall J.O. (2017). An investigation of feeding high-moisture corn grain with slow-release urea supplementation on lactational performance, energy partitioning, and ruminal fermentation of dairy cows. Can. J. Anim. Sci., 97: 742-752.

Tyrrell H.F., Reid J.T. (1965). Prediction of the energy value of cow's milk. J. Dairy Sci., 48: 1215-1223.

Van Soest P.J. (1994). Nutritional ecology of the ruminant. Cornell University Press, Ithaca, NY, USA. https://doi. org/10.7591/9781501732355

Van Soest P.J.J., Robertson J.B.B., Lewis B.A.A. (1991). Methods for dietary fiber, neutral detergent fiber, and nonstarch polysaccharides in relation to animal nutrition. J. Dairy Sci., 74: 3583-3597.

Wattiaux M.A., Karg K.L. (2004). Protein level for alfalfa and corn silage-based diets: II. Nitrogen balance and manure characteristics. J. Dairy Sci., 87: 3492-3502.

Received: 26 I 2021

Accepted: 24 VI 2021 